\title{
AMOR \& IDEOLOGIA EM JORGE AMADO
}

\section{Vicente Ataide (UFAL)}

\section{CASAMENTO: A VIOLAÇÃO BURGUESA}

Crítica ao modelo burguês de casamento - Jorge Amado propõe. nos melhores romances que envolvem o tema (Gabriela, cravo e canela, Dona Flor e seus dois maridos, Tereza Batista cansuda de guerra, Tieta do agreste) a hegemonia do amor, jamais a hegemonia do casamento. O casamento é uma burla, a contraparte da felicidade e da completação amorosa, tanto psicológica quanto física. As mulheres traem os maridos, não têm vergonha de fazê-lo, pois as necessidades da psique e do corpo são maiores do que a convenção social burguesa. Os maridos vão buscar nos bordéis, nas amantes, o encontro perfeito para as necessidades do sexo. Jorge Amado não tem compromisso com a hipocrisia burguesa do casamento.

Dentre muitos exemplos, há que citar a oposição entre Julieta e Raimunda (São Jorge dos Ilhéus). Raimunda, filha da terra, tem algo à ancestralidade indígena - remove o chão, planta. colhe. Verdade que é um plantio para a subsistència, de olho na grande plantação de cacau, mas o exemplo não deixa de ter expressividade, pois Raimunda é un ser autêntico que, como as suas ancestrais, tem uma posição no conjunto social, sabe dessa posição e a sustenta. Não é um adorno, como Julieta e as muitas mais. O marido, Antonio Vítor, sabe que "devia sua prosperidade atual a Raimunda". Não se trata de rasgo lirico. contemplação, mas de atuação social e individual que só a mulher tem conseguido no romance brasileiro, pelo menos (Senhora, lidas secas, Dom Casmurro. Uma aprendizagem ou o livro dos prazeres). Não é o casamento ou o encostar-se no homem que faz de Raimunda o ser humano, é o trabalho, a participação no conjunto social, a descoberta e o valor de sua função social, o encontro/revelação de sua subjetividade: ela se opõe ao marido quando necessário, argumenta, tem ponto de vista próprio, afinal, tem uma identidade que não é reflexo do outro, mas resultado do embate com a vida e consigo mesma. Compreende a significação do trabalho. embora esteja num contexto que a escravize, pois o trabalho, a rigor. 
não renderá do melhor nem para ela, nem para os seus. Tem sentimentos, dificeis de serem entendidos, haja vista que as mulheres comentam que Raimunda "sempre foi besta... Desde que morava com os Badarós..." (p. 87). Mas o que ela sente é profundo e duradouro, fiel e inteligente. A individualidade do ser, principalmente do ser feminino, não se marca pelo sentimento, pelo amar um homem, pelo fechar-se e entregar-se - como enclausura o pensamento burguês. É, antes, no entender o todo e no entender-se, garantindo sua participação na sociabilidade. Raimunda faz isso, assim sendo.

Julieta é menos a mulher burguesa e mais a mulher do burguês: trancafiada, sem destino histórico, sem projeto de vida. Quando muito, desempenho sexual para gáudio do senhor seu homem - coisa, de resto, pouco comum entre os burgueses, já que o comum é o prazer sexual ser encontrado com outro parceiro. A via sexual pode ser um caminho para a descoberta da individualidade, mas ele é restrito, não gerando conseqüências mais graves na luta social, embora possa abrir portas para a descoberta da subjetividade. Em Jorge Amado, para a burguesia não há solução. Julieta, riquíssima, é nula, sem perspectiva, sem norte: angustiada, desesperada, neurastênica. O sexo não lhe resolve o sem-sentido da vida, pois ela sabe que depois “a tristeza, a angústia, a 'neura', [serão] ainda maiores e mais terríveis. Mas assim passava naquele crepúsculo, a ânsia sem sentido, aquela dor sem explicação, aquele vazio total que a matava" (p. 205). O desenho não pode ser mais claro. Outras mulheres estão nos mesmos limites, a galeria não tem fim. O escritor consegue identificar as causas do problema e ele atravessa todos os seus livros. Por outros termos: a mulher burguesa não tem solução, não consegue atingir a subjetividade. Sempre será objeto, coisa, não raro, posse sexual ou ladeira para subida econômica do outro. O que só faz aumentar a angústia, o vazio total. No caso particular de Julieta, Jorge Amado tentou a descoberta de valores, mas a cena é falsa. Valores de Julieta até conhecer o poeta Sérgio Moura: dinheiro, luxo, negócios, coquetéis, festas. Depois: pássaros e livros, flores e versos, frases, gente, sentimentos; belo x útil, dinheiro x poesia: "a língua era capaz de realizar milagres na criação de mundos de palavras, mundos mais reais que o triste e pobre mundo rico em que ela vivia" (p. 206-8).

Não foi o sexo o viés que permitiu a Julieta descobrir que havia outro universo, além daquele de que fazia parte (ela já tinha tido outros amantes, que nada acrescentaram). Foi a poesia o modificador, 
poesia como forma de descobrir o mundo e a si mesma, este, sim, um viés capaz de levar à subjetividade e à individualidade, revelando a Julieta um todo que nada tem de vazio, mas que está pleno de festa, de comunhão, de humanidade - de homem humano, como lá descobre Riobaldo, outro que anda à procura de preencher seus vazios. $\mathrm{O}$ irônico da cena: é o poeta que faz emergir o conhecimento em Julieta, justamente o poeta, o primeiro a ser expulso da cidade e mais expulso ainda da cidade burguesa. No conjunto, porém, todo o movimento de Julieta é inverossímil - é possível, mas não é crível.

Sabe tanto isso Jorge Amado [contrariamente a seu patrono na Academia de Letras, José de Alencar, cuja Lucíola se rende à maternidade como forma de resgate da feminilidade e da condição social da mulher], sabe tanto isso que Tereza Batista não duvida entre o amor de mulher e o amor de mãe: opta pelo amor de mulher, fica com o doutor e refuga o filho. Momento agudo na literatura brasileira, raramente discutido de modo tão claro: Tereza Batista não duvida, embora fiquem marcas de saber um filho lançado no estrume. Pior que o aborto consentido, na mesma cena, seriam as conseqüências, imediatamente discutidas, do filho de rameira - no fundo, do filho de qualquer mulher pobre. A protagonista assume um papel definitivo no conjunto social, modificando tudo o que está dado na sociedade burguesa: "Alguns presentes, a caixa de música, por exemplo, [...] deixavam-na deslumbrada. Prezava cada objeto, cada regalo, cada mimo, mas poderia viver sem eles; só a ternura, o calor dos sentimentos, a atenção constante, a doce amizade, o amor, lhe farão falta. Se escolheu o amásio na hora da opção, ela o fez porque o situava acima de todos os bens da vida, até de um filho: para mim o senhor passa antes de tudo" (p. 903-4 - 4a parte, cap. XXI). Voltando ao mesmo Alencar, é Tereza, nessa opção, semelhante a Aurélia Camargo, a senhora, a que opta pela feminilidade que não depende da maternidade. Ao mesmo tempo, a protagonista de Jorge Amado descobre sua individualidade, a marca que a identifica no todo social: a mulher que faz opção tão grave não será mais a mesma: é um ser social capaz de modificar o estatuto que aí está, modelado pelo burguês.

Ao mesmo tempo, o escritor não permite que haja a reificação do ser: Tereza ou Gabriela poderia apossar-se de bens, vivendo na indolência ou no interesse, reduzindo-se a coisas. Nada disso, são mulheres, sobretudo Tereza, que têm inteligência (o texto chega a 
dizer que ela é um azougue), não distinguem sentimento e razão, pois fazem algo melhor e mais, são seres que se apropriam de sua humanidade e não se rendem às solicitações materiais ("o doutor sabia que os interesses materiais não pesaram na decisão" - aquela de recusar o filho e ficar com o homem amado: Emiliano Guedes se retiraria da relação e não emprestaria seu nome à criança, mas nada faltaria a Tereza e ao filho). De modo geral, as protagonistas de Jorge Amado não são movidas pelo dinheiro - são-no pelo amor, pela oferta do sentimento e do corpo a que se alia, em alguns casos, a inteligência - a inteligência foi uma descoberta que veio sendo feita aos poucos pelo escritor, já que a individuação, a sociabilidade que envolve tanto o homem quanto a mulher, não se pode operar em apenas um padrão, v.g., o sentimento.

A contraprova da não-reificação de Tereza advém da proposta reificadora do médico - o mesmo tão rigoroso de princípios que recusara a Tereza o aborto, mas não resiste ao menor chamado do dono da usina (no caso, pai da criança): o médico propõe ao amante que traga à amada uma boneca, "dessas bonecas grandes", a fim de substituir o filho abortado. Emiliano Guedes entende que Tereza não é só bonita e jovem, mas é também sensível e inteligente: a substituição seria uma anormalidade. E dá a tese não reificadora: "Se uma boneca pudesse substituir um filho, tudo no mundo seria fácil."

A conquista da individuação e da subjetividade - Tereza não é só sentimento, é também inteligência; não é um boneco que se possa trocar de lugar como bem se entenda - essa conquista envolve a totalidade do ser, envolve suas defecções e assunções diante do mundo, dos homens e de si mesmo. Que é o que acontece com Tereza Batista.

O amor, de que fala Emiliano, ao contemplar o médico que se retirava, dá a dimensão maior do ser humano em sua humanidade, coisa que o modelo burguês destrói ou não considera.

Toda a casta de hipocrisias sociais: imprensa que cria ambiente propício aos empresários, a especulação imobiliária, o submundo da prostituição, o arbítrio do poder político e econômico, o despotismo dos coronéis e dos capitalistas nacionais e estrangeiros, com poder de vida e morte sobre todas as pessoas, o arbitrio policial, tudo está presente na fícção de Jorge Amado, criticado impiedosamente pela malícia e pelo humor. 
Desde os primeiros momentos da obra do escritor, com narrativas engajadas, romance documental, obras de contestação e denúncia social explícita, nas quais o pobre e oprimido sofre sob o cutelo do opressor, do latifundiário, do senhor de terra ou do capitalista, as contradições econômicas e sociais do Brasil, agroexportador de bens primários, até as narrativas preocupadas com o episódio, o anedótico de uma situação existencial (a partir de Gabriela, cravo e canela, 1958), a crônica de costumes e a pesquisa consciente do sincretismo afro-brasileiro, sobretudo nagô, afinal, em qualquer dos momentos, Jorge Amado jamais perde o traço da crítica social, a mostrar por dentro o desempenho do burguês explorador contra a utopia do oprimido por um mundo socialmente melhor e mais perfeito.

\section{JORGE AMADO, AMADO}

Considerando dois livros - Terras do sem fim e São Jorge dos Ilhéus -, dá para entender a consciência que tem o escritor sobre os principais problemas econômicos e sociais brasileiros e algumas de suas formas de dependência. Num primeiro momento, descrito no primeiro livro, o conquistador brasileiro busca o domínio da terra. Luta, se expõe ao perigo, vence. Entra no processo de produção (no caso, cacau; poderia ser açúcar, ouro, café, borracha, soja). Os maiores produtores, aqueles que possuem maior quantidade de terras, não sabem senão exportar seus produtos - quem fica com a melhor parte são os que estão na outra ponta, tal qual havia acontecido com o açúcar, com o ouro, com o café, com a borracha. O romancista entende a estrutura e a situação periférica do Brasil: é um país exportador de matéria-prima, monocultor e de extensos latifúndios. A maior parte dos problemas nacionais advém dessa organização. As formas de pensar e de estruturar a sociedade estão fincadas nas suas formas de produção - não há bibliotecas, não há arte, não há lazer, não há ócio para as camadas sociais baixas. Só interessa produzir, expandir a propriedade, ganhar dinheiro na alta, estar de bem com os compradores estrangeiros. Fica nítida a situação nos vários romances do escritor: só produzir cacau - não há mais nada. O que acontece em volta, deve-se ao cacau e à sua expansão: prédios altos (urbanização), casas exportadoras (no começo brasileiras, depois, absorvidas pelos grupos estrangeiros), bancos, grandes hotéis, as luzes e o brilho do 
centro, os contrastes com a periferia dos deserdados - "um bairro escondido em sua miséria" (cf. p. 68, 150 e passim de São Jorge dos Ilhéus). A religião a serviço dos poderosos e estes àquela assistindo: Carlos Zude ou qualquer coronel sabia investir na igreja, no órgão ( $p$. 181), numa construção. Em troca, recebiam a ideologia deica repassada aos pobres, não deixando que eles se libertassem: "As dívidas não diminuíam, aquilo não tinha mesmo jeito nenhum. Era assim, sempre fora assim, era destino. 'Destino se faz lá em cima', diziam as velhas, num fatalismo, apontando o céu. Para elas só havia uma longínqua esperança: era a outra vida, o céu, onde os mais pobres seriam mais ricos" (p. 271). É dificil perceber o quanto a religião é um logro. Enquanto isso, tome riqueza para os ricos, às custas da exploração.

Numa palavra: nada há que não deva sua existência ao cacau, isto é, à monocultura exportadora. E nenhum brasileiro participante do processo de produção sabe o que fazer com o produto, é só exportar in natura. Logo no começo do romance, aliás, há o rumo que deverá seguir a narrativa, numa reflexão a seu tanto amarga de Don'Ana Badaró: o casamento, o nascimento de filhos, a morte do menino, a morte do marido, os casamentos das filhas "tinham sido acidentes mais ou menos importantes, porém acidentes. O importante era o cacau e somente o cacau". A voz da velha matrona, agora empobrecida, é um ressôo do que coordena a vida de todos.

A ficção de Jorge Amado sabe que ser proprietário de terras é fundamental, o latifúndio é a base de sustentação econômica e social, o poder advém da propriedade de terras: Carlos Zude (p. 22) sonha com as terras e delas ser proprietário: naquela estrutura só quem é proprietário tem poder: "era essencial possuir terras" (p. 163). Aquele coronel Horácio da Silveira, que veio das lutas épicas das Terras do sem fim, mesmo paralítico, velho, quase cego, tem o poder, "fazendo e desfazendo autoridades, senhor de milhares de votos, rico de incalculável riqueza, rico de fazer medo, como diziam em toda a extensão daqueles municípios" (p. 92), o coronel Horácio só é poderoso porque é dono de terra.

Os ensaístas brasileiros sabem disso (Vítor Nunes Leal Coronelismo, enxada e voto; Caio Prado Júnior - Formação do Brasil contemporâneo; Nelson Werneck Sodré - História da burguesia brasileira; Florestan Fernandes - A burguesia brasileira; Raimundo 
Faoro - Os donos do poder), mas Jorge Amado dramatiza a realidade brasileira numa ficção que deixa muito claro o real. Como os capitalistas conseguem apoderar-se das terras é o elemento condutor de todo o São Jorge dos Ilhéus: a simulação da alta, o esbanjamento da riqueza em frivolidades - talvez seja o caso de entender, com Jorge Amado, que o latifundiário brasileiro não sabe o que fazer com a riqueza e com os bens amealhados: "Horácio era uma das maiores fortunas da zona do cacau. [...] Levava, no entanto, a mesma vida frugal dos tempos de antes, nenhum luxo na casa-grande, fazia economias de tostão como se fosse pobre, reclamava contra o dinheirão que o filho gastava" (p. 99) Ele nunca vai deixar de ser aquele "tropeiro que tangia burros pelas estradas recém-abertas do cacau" (p. 214). Não tem olhos de ver. E, portanto, a afirmação explícita: "os coronéis não sabiam o que fazer do dinheiro" (p. 195). Gastam uma fortuna em coisas desimportantes, acendem o charuto com notas de dinheiro - este não saber o que fazer vai perdê-los, pois não acompanham a transformação histórica. A riqueza vai trazer os capitalistas nacionais, depós eles, os estrangeiros e o imperialismo. Terras do sem fim e São Jorge dos Ilhéus são o melhor quadro que Jorge Amado pintou sobre a realidade brasileira, absorvendo-lhe os maiores índices de complexidade e riqueza.

Assim como, profeticamente (Antônio Houaiss), ele já tinha feito em relação aos meninos de rua (Capitães da Areia), também aqui Jorge Amado denuncia e dramaticamente expõe a situação da criança pobre brasileira (p. 154-5).

Outro tanto acontece com a ecologia: "a derruba das grandes matas diminuíra as chuvas" (p. 36); o resultado ecológico da devastação da mata faz os homens olharem para o céu e se angustiarem, mal percebendo que eles mesmos haviam provocado o desequilíbrio (pp. 77-8); as mesmas interrogações e as mesmas angústias vão continuando, bem como a causa predatória: "Depois que os últimos restos das grandes matas haviam sido derrubados e plantados, não mais foi tão constante e farta a chuva nas terras de Ilhéus" (p. 168); "Não se ouviam senão bendições àquela chuva" (p. 181). O que Jorge Amado descreve para a zona cacaueira pode ser aplicado a qualquer outra região brasileira (basta recordar o clássico ensaio de Franklin de Oliveira - Rio Grande do Sul, um novo Nordeste). Segundo meu conhecimento, o norte do Paraná, região de Londrina ou Maringá, nos anos cinqüenta para sessenta, tinha água em 
até três metros. Hoje, são precisos mais de cento e cinqüenta. Sobrevoar a Amazônia é ir chocando-se com grandes bolsões de desmatamento arbitrário e irracional. Tudo está claro na ficção de Jorge Amado.

\section{O DOMÍNIO POLÍTICO}

Não existe obra de Jorge Amado em que o problema não venha à tona, seja para ironizar o poder, seja para utopicamente desejar um melhor mundo, mais justo e equânime. Como o político está atrelado ao sistema econômico, as modificações deste implicam em modificações naquele. Assim, há o tempo dos coronéis e há o tempo dos capitalistas - neste, a sociedade mais complexa exige mais empenhos do sistema econômico: a classe dos trabalhadores começa a se organizar e a participar do processo político com vistas à mudança econômica e social - "Além do Partido Comunista (que nunca era contado entre os partidos existentes, já que era rigorosamente ilegal) existiam o partido do governo e o da oposição, iguais os dois, com a única diferença de que um estava no governo e o outro desejava o governo, e a Ação Integralista, que era o partido fascista, sustentado, segundo diziam, pelas casas exportadoras" (p. 71-2). Jorge Amado entende de política e, mais que tudo, de politica brasileira. Ele conhece o significado profundo de república velha, mundo dos coronéis, lavoura, e de república nova, mundo dos capitalistas, agroindústria. O movimento interno das modificações por que vai passando o Brasil, as atitudes das pessoas como determinadas por essas modificações, a complexidade do todo social, pois a estrutura econômica se está tornando complexa: já há uma classe média e um operariado que começa a se sindicalizar. Qual o pensamento e a ação dos homens nesse conjunto?

No tempo dos coronéis, o poder de vida e de morte, o mando do voto, qualquer indivíduo votava naquele que o coronel determinasse (cada enxada era um voto) - e muitos são os romances brasileiros que trazem essa matéria (A bagaceira, 1928, Fogo morto, 1943. O tempo e o vento, 1949-61. O coronel e o lobisomem, 1964).

Jorge Amado deixa um tanto de lado, devido aos graves problemas do tempo em que foram escritos seus livros - de 30 para 45 - o crescimento dos movimentos operários e camponeses, para 
dedicar contundentes páginas aos conflitos entre integralistas e comunistas = direita e esquerda (cf. os ensaios de Hélgio Trindade Intregalismo: o fascismo brasileiro na década de 30; José Chasin - O integralismo de Plinio Salgado: formas de regressividade do capitalismo hipertardio; Hélio Silva - Terrorismo em campo verde).

O romancista entende o problema e sabe avaliá-lo em toda a extensão. Com isso, seus livros não se prendem ao exótico brasileiro. à erotização de mulatas e morenas, ao tropicalismo sensual e preguiçoso, enfim, aos diversos índices da ideologia do colonialismo dos paises dependentes. Jorge Amado entende o problema numa perspectiva global, pois os golpes do imperialismo, mesmo o tardio, são dados com vistas a prender cada vez mais o ser humano em suas malhas, não the dando liberdade. Daí a crise que começa a aparecer em plano brasileiro: pequenos grupos adquirem consciência crítica e denunciam as manobras do poder econômico.

As querelas dos partidos políticos, os grupos do governo e fora do governo (p. 72), não chegam a ser graves nesse momento, se bem que dão a base de sustentação para a emergência das idéias radicais. O escritor anuncia grupos em conflito: anarquistas, comunistas e socialistas, fascistas e nazistas (p. 74). As classes sociais já estão fechadas, não se misturam, a luta é visível nos menores segmentos sociais (pelo menos entre aqueles que têm um tanto de consciência crítica). A realidade brasileira está mudando, pois a estrutura econômica já não é a mesma - o tempo dos coronéis chega ao tim. A classe média começa a assumir importante papel político e os sindicatos de trabalhadores, a partir de uma visão anarquista ou ingênua, cresce em poder de organização. A ficção de Jorge Amado constrói paralelamente os dois movimentos: as duas classes dominantes em conflito. No plano brasileiro, a ascensão do integralismo foi decisiva.

\section{A NATUREZA DO ÓDIO FASCISTA}

As oligarquias que não se adaptaram aos novos tempos vão sucumbir. De modo geral, isso aconteceu com o coronelismo. Seus herdeiros, contudo, encontraram outros caminhos e o capitalismo hipertardio - chegado junto com o fascismo e com o nazismo - soube aproveitar os descendentes ricos do coronelismo, cooptando-os para a 
causa imperialista. Como a história não perdoa, o capitalismo hipertardio teve que partir para a agressão a fim de conquistar o espaço econômico que estava bloqueado pelos que haviam chegado antes e se apossado de tudo. A luta, no plano maior, repercute imediatamente no Brasil. Foi o que houve com o integralismo, forma tupiniquim de fascismo. Os camisas-verdes, como eram chamados devido ao uso identificador desse vestuário, conquistaram espaços extraordinários em todos os setores da vida nacional. Plínio Salgado, o líder nacional, chegou a um fastígio tal que poucos atingiram tão altos índices de consagração. Pode-se dizer que, em conclave no Rio de Janeiro, em 1935, proporcionalmente foi o maior encontro político já havido no país em todos os tempos. Jorge Amado, lúcido, sabe o que significa o integralismo: imperialismo que perdeu o barco da história, direita retrógrada, ódio; apropriação de todas as formas possíveis de produtos e bens duráveis a fim de recuperar o tempo perdido e atrelar o carro econômico à situação presente. Assim, investiu esse capitalismo em todos os cantos do mundo nos quais pudesse haver matéria-prima útil à indústria: tudo foi vasculhado, como sói acontecer com o imperialismo, para atualizar-se. E veio, ainda uma vez, o desencontro: a África estava tomada, a Ásia estava tomada, a América Latina estava tomada. Não havia mais fornecedor em lugar nenhum. Ou partia para a luta ou não se atualizava. Só restava o caminho da
luta.

$\mathrm{Na}$ particularidade romanesca, como isso se opera? Com astúcia, Jorge Amado se utilizou da luta entre o coronel Horácio e Silveirinha, pai e filho (p. 212), para deflagar a matéria, rica no tempo de elaboração dos romances do autor.

O poeta Sérgio Moura discutia com o trabalhador Joaquim (filho de Raimunda e Antônio Vítor) o "verdadeiro significado da luta" (p. 213), cuja resposta só vai ser entendida muito na frente, à p. 339 , quando os integralistas não apóiam Carlos Zude/Karbanks (Carlos Zude eleito, Karbanks vai mandar) para prefeito. Imperialismo norte-americano $\mathrm{x}$ imperialismo hipertardio nazi-fascista (os integralistas pertencem a esse último grupo). Entende-se com facilidade por que o imperialismo ianque é agredido em campanhas violentas pelos integralistas. Eles mesmos que, durante muito tempo, estiveram buscando o poder político, mas não se digladiavam frontalmente, agora em franca luta aberta de oposições: o capitalismo imperialista praticado por Estados Unidos, França, Inglaterra, 
Holanda, Bélgica, entre outros, mandava as ordens para todos os quadrantes. As repercussões no Brasil vieram logo.

Isso tudo, porém, da história e da ficção, ainda não clareou a natureza do ódio de Silveirinha - total, corrosivo, absoluto, sem tréguas. Silveirinha é o líder integralista escolhido para o comando na zona do cacau. De um lado, por ser filho do mais poderoso coronel (coronel e integralismo não se afinam muito bem), capaz de substituir o pai no poder econômico e, ipso facto, no mando. De outro lado, Silveirinha seria excelente fonte financeira para o movimento - os parceiros chegavam a ironizar sua posição: "Silveirinha não tinha ilusões e sabia que havia sido eleito pelo dinheiro, sabia que existia, no partido, quem risse dele, da sua incapacidade como orador" (p. 219). Schwartz, empresário alemão, chega-lhe a ter nojo e desprezo e os líderes do "partido se riam, pelas costas, de Silveirinha" (p. 213). Talvez haja um outro motivo, mais profundo e perfeito: o ódio. $\mathrm{O}$ texto, na cena, chega a falar "na mata amedrontadora", os arcanos de labirintos inconscientes e escusos, talvez. Assim, de massa de manobra dos grupos de interesse, Silverinha teria motivos maiores para ser o líder: não conhecerá fronteiras para bater os inimigos.

O ódio de Silveirinha é, então, mais ou menos nebuloso. Carência afetiva de todo lado - o único que lhe poderia ser amigo, 0 médico dr. Jessé, morre; a ama-de-leite, Felícia, que o criara desde a morte da mãe, é estimada "como se gosta de um cão" (p. 216). Ao mesmo tempo, fonte do ódio ao pai, a frustração por não saber quem é com certeza seu pai; o ódio à mãe por ser adúltera; confusão psicológica total - o que permite aproximá-lo daquela Julieta vazia e sem norte. Dividido e menorizado, Silveirinha é o melhor produto burguês apresentado por Jorge Amado: "Talvez o que tenha levado Silveirinha para o fascismo, mais que qualquer convicção de ordem política ou qualquer simpatia pelas idéias pregadas pelo partido, fosse a festa de sangue que os integralistas anunciavam para quando tomassem o poder" (p. 215). Por que a festa de sangue? Para o partido, porque o comunismo devia ser banido - o comunismo propõe o contrário do fascismo: concentração x distribuição. Para Silveirinha, em particular, para satisfazer a angústia de sua incompletude. O ódio era a razão de sua vida, diz o romance. As duas coisas, aqui, se dão as mãos: o partido e Silveirinha são farinha do mesmo saco. O ódio é que os tange no caminho da história. 
O que Silveirinha não entende é a rapinagem dos integralistas, que não titubeiam em jogá-lo contra o pai para que ele se apossasse do dinheiro, controlado pelo coronel. De um lado, a causa maior do movimento fascista; de outro, a luta intestina entre os fazendeiros de cacau e os exportadores - ter em mãos as propriedades de Horácio da Silveira era um trunfo decisivo. A luta filho contra pai, tramada por Schwartz e encaminhada por Gumercindo, é a fachada de um interesse mais amplo: a posse das terras pelos exportadores. Nesse contexto, os integralistas estão servindo a uma causa brasileira, não cientes de que o problema envolvia facetas internacionais do imperialismo e a hegemonia de grupos.

Num primeiro momento integralista, todos os exportadores estão unidos, contribuem com dinheiro para a causa. A conivência dos fazendeiros se dá menos por convicção do que por pavor ao comunismo: "numa coisa estavam de acordo todos: os fazendeiros, os exportadores, os padres, os comerciantes. Era na necessidade de combater o comunismo" (p. 221). A esperta campanha anticomunista dava resultados: as filhas dos homens de bem seriam prostituidas, as terras tomadas, o coronel iria trabalhar na enxada. Gumercindo, pau mandado dos lideres integralistas, vivia com panfletos nos bolsos, mostrando-os aos coronéis e aos indecisos. Não tinha nenhuma dificuldade em convencê-los. Depois eles romperão entre si - grupos do eixo e grupos americanos (p. 360). Mas, então, o domínio sobre as terras já será total: o tempo dos coronéis havia terminado.

[O combate ao comunismo é um equívoco do fascismo, que deslocou o seu ódio hipertardio - deveria odiar os imperialistas, que
lhe não davam espaço.]

\section{SONHO \& UTOPIA}

A ficção de Jorge Amado, contudo, não fica apenas olhando para uma banda do mundo. Procura, dialeticamente, a compreensão da totalidade. Assim, não falta a perspectiva do trabalhador - operário e camponês.

A personagem que vai centralizar as indagações do autor é Joaquim. Saído da pequena propriedade rural, sem futuro no mundo latifundiário, Joaquim é operário e, aos poucos, vai-se tornando líder de sua comunidade. Atravessa da inciência para a ciência. Aos poucos, 
a cada problema novo enfrentado, entendendo a realidade social e econômica, conversando com o poeta Sérgio Moura (de novo a poesia como fonte de conhecimento), ele mesmo refletindo sobre a totalidade, chega à utopia de um novo mundo sem classes e sem privilégios.

O ápice da alegria de viver está no período de alta do cacau quando há riqueza, há alegria de viver (mal sabiam os fazendeiros que a alta era o prelúdio da derrocada). O poeta Sérgio Moura se interroga: por que a alta? E estabelece que ela nada adiantava para os trabalhadores (p. 57). A partir daí, a consciência político-social de Joaquim tende a crescer. Na prática, na luta para envolver os demais trabalhadores, mais e mais ele vai entendendo a situação. Dramaticamente - Jorge Amado constrói um romance engajado -, as perguntas vão sendo feitas, mas as respostas só são obtidas aos poucos, na demanda do conhecimento. Às vezes, até, o fato aí está, mas o equacionamento do problema não é conseguido - como no caso da alta do cacau: "Havia um mistério sob aquela coisa da alta? Que diabo seria?" (p. 58). O romance levanta o fato, problematiza-o e deixa que os acontecimentos venham à tona para que a reflexão chegue à teoria. $\mathrm{O}$ romance é um livro de enseñanza. O aprendizado se faz no embate com a vida. Pelo menos para Joaquim, personagem do aprendizado.

Joaquim, engajado num partido político de esquerda, luta a fim de que os trabalhadores das roças de cacau se politizem e comecem a cobrar a melhoria de vida que suas propostas filosóficas exigem. Porém, encontra uma barreira decisiva: a ignorância. Os trabalhadores das fazendas eram "homens que não sabiam ler nem escrever, que vinham das lutas pela conquista da terra, muitos deles, um misto de camponeses e assassinos, tinham certa apatia diante da miserra que os dobrava como escravos. Só uma palavra chegava a interessá-los vivamente: terra" (p. 71). Para chegar ao mínimo de politização, é preciso sair da ignorância. O conjunto de fazendeiros, exportadores, padres e comerciantes não vai admitir escola, livros, debates, reuniões, sindicatos. Só a pulso, os pouquíssimos letrados (poeta) e um que outro trabalhador conseguirão parlamentar com a maioria, a fim de thes mostrar outro viés histórico, que a vida pode ser modificada pela vontade dos homens. É tarefa de Joaquim, principalmente, e do poeta Sérgio Moura. Do contrário, o trabalhador vai continuar escravo (p. 72), alugado (p. 89), sem futuro nem perspectiva (p. 108); até as crianças já estão na labuta: "Os meninos 
ganham quinhentos réis por dia de trabalho, estão nus, as barrigas enormes, parecendo de mulher grávida, meninos empapuçados. É da terra que comem, terra gostosa, que supre o alimento que falta. Ficam todos - negros, brancos e mulatos - de uma mesma cor amarela, ficam parecidos com as folhas dos cacaueiros" (p. 113). Nem idade, nem sexo, nem cor, ninguém escapa ao regime de exploração.

As condições de trabalho não são melhores: a morte ronda por todo lado, a fome endêmica, doenças, o arbítrio do capataz (tanto pior é se tinha sido trabalhador igual aos outros, pp. 110-3) - é o caráter espúrio da cultura brasileira. Joaquim, que consegue ver o problema, conversa, insiste, mas suas palavras caem no vazio. Parece que a ignorância cria uma crosta intransponível entre o ver/viver e o entender. Ele sabe, contudo, que a sua luta é essa, que é preciso ir em frente, sem descanso, o tempo todo para que haja algum luzir em algum ponto. Para, então, chegar ao clarão da utopia. Joaquim ainda está nas vascas do pesadelo. Nem sonho há.

O trabalhador nem sabe do produto do seu trabalho ("De chocolate tudo que esses 'alugados' conhecem é esse cheiro parecido que o cacau tem", p. 124), morre sem mais nem menos, como no caso da estufa - Jorge Amado apanha muito bem a crudelidade do sistema homem $x$ cacau: o sistema destrói o homem, pois ao morrer um trabalhador [e vem aquela lengalenga trazịda pela religião de chegou o dia, deus quis, é o destino, é melhor morrer estuporado - choque térmico - do que "levar meses na cama, magro e amarelo, morrendo devagarinho" (p. 126)], ele é substituído por outro, como objeto descartável. O trabalho não vale, a vida não vale, o homem não vale só o dinheiro vale. O homem é mercadoria (cf. a reação do coronel Frederico Pinto, pp. 127-8, diante do cadáver de Ranulfo: "Felizmente salvou-se o cacau..."). Ou a reação dos companheiros, sobretudo Varapau, ao explicar que "a gente ia enterrar ele que nem um bicho, um bicho do mato" (p. 178). Escravo, mercadoria descartável, bicho, coisa: essa a condição do trabalhador.

Jorge Amado, humanista, apieda-se de todos os seres que sofrem. O mesmo humanismo faz com que zombe dos que causam o sofrimento. O escritor, na voz do poeta, sabe que há outro mundo, de coisas mais puras e mais heróicas, que há, segundo a simbolização, flores, pássaros e uma revolução de que fala Joaquim (p. 297). Se um mundo bom está no sonho, é preciso alcançá-lo no real. O ser 
revolucionário não se deixa coisificar, pois ele tem consciência das contradições do real, dos privilégios e da exploração. Tem consciência de um outro mundo que é preciso atingir pela luta: "seus ideais políticos, do mundo futuro, da fraternidade, de igualdade, de amor para todo, com que sonhava e pelo qual se batia" (p. 298). A busca da utopia e Joaquim a se transformar numa metáfora luminosa e quente: todos os joaquins do mundo - os homens e as mulheres.

A utopia dialética: "vai começar outro tempo, companheiro. Houve o dos conquistadores, agora é o dos exportadores, depois será o nosso tempo" (p. 311). Para a lide, o operário vai chamar o camponês a fim de estabelecerem a via organizacional - cangaço e banditismo não são soluções, assim também nada resolve o messianismo daquele profeta que, desde os tempos do Sequeiro Grande, anda "pelas estradas repetindo velhas profecias" (p. 340). Em face da ignorância, do analfabetismo, a tarefa de esclarecer e entender vai devagar, pouco rende. Mas a fome é aliada poderosa: entre o cangaço e o profeta, o povo começa a ficar com a palavra de Joaquim, que cobra reuni-los para exigir comida. Há que unir, juntar, pois os ricos são unidos e organizados e impõem seu pensamento e sua práxis. "Pobre não tem direito porque não se junta, não se une para lutar pelos seus direitos" (p. 329).

\section{UM LIVRO DE APRENDIZAGEM}

Jubiabá (1935) é um libro de enseñanza. É a estória das transformações de Antônio Balduíno: ele passa da insciência para a consciência (crítica). O texto deixa explícito que o protagonista aprendeu muita coisa ao longo da vida e que a aprendizagem o transformou: "o moleque Antônio Balduíno aprendeu na sua infầncia" (p. 29), "ouvia e aprendia" (p. 37), "ouvia e aprendia" (p. 41),
"aprendeu desde cedo no exemplo diário dos maiores" (p. 41). Há que destacar que as estórias que ele ouve ou que convive no Morro do CapaNegro são a "sua aula proveitosa" (p. 26). Esta escola, normalmente, aponta para dois caminhos: a) as crianças vão ser malandros, desordeiros ou ladrões - não esquecer uma visão carnavalesca que Jorge Amado imprime à sua cosmovisão: ao cabo, essas figuras são heróis na leitura da gente do morro; b) vão ser escravos das fábricas, do campo ou dos pequenos ofícios. Não há saída. Salvo quando algum dote natural transforma o produto desse meio. 
O protagonista já apresenta qualidades naturais, como força e esperteza, liderança e chefia, inteligência e sensibilidade. Com Zé Camarão, um dos seus ídolos do morro, aprende as lições de música, capoeira e o não-trabalho. Zé Camarão nega-se a trabalhar para esse mundo que aí está. Antônio Balduíno aprende isso com facilidade e rapidez.

As estórias que Antônio Balduíno ouve, relatam:

1) Os feitos de cangaceiros: Lucas da Feira - toma do rico e dá ao pobre, é um namorador inveterado, fidelidade à palavra e à amizade, heroísmo; porque gosta de brigar, Balduíno quer ser jagunço. Como os cangaceiros têm um abecê que lhes narra os feitos, Balduíno entende que terá o seu abecê logo que pratique os grandes atos dos cangaceiros.

2) As estórias de mulheres seduzidas -- crença no feitiço ou no destino talhado nos céus (Antônio Balduino vai desmentir essa noção de destino: os fatos humanos são produzidos pelo homem e este pode alterá-los pela vontade); os homens se comportam de modo soez para com as mulheres (o logro perverso é a marca desses sedutores - aos poucos, o protagonista pode entender que esse não é o caminho do amor - embora ele mesmo venha a se tornar um grande namorador).

3) Aprendizado das forças primárias do bem e do mal (Jubiabá usa as metáforas do olho da piedade e do olho da ruindade) - as estórias de João Janjão (nega água a um sedento e mata o amigo que o carregara nas costas porque este queria dar água ao sedento); as estórias de Jeremias de Ilhéus (vida e morte na zona do cacau); a estória de Zé Estıque (rico que perpetra toda sorte de maldades). Os privilégios de delator, aquele que trai o seu grupo social - caso de Balbino, que entregava negros do morro para a polícia. As estórias ouvidas dão o norte ético de Antônio Balduino.

4) Narrativas do maravilhoso - o caso de Augusta das Rendas, que possui um encosto que dela não se separa (ex-marido?, exnamorado? - "Minha vida é um romance... É só escrever...", diz ela, p. 42); o caso do lobisomem que aparece no morro. Antônio Balduíno pensa em virar lobisomem e pratica todos os atos necessários para. $\mathrm{O}$ maravilhoso vai ser superado pelo material e concreto, assim como as crenças religiosas, sempre desmentidas por Antônio Balduíno. 
5) O aprendizado da dor humana como um fato natural de que não se pode desviar - a loucura de Luísa, o sofrimento dos homens comuns do morro, o estranho assassinato de Leopoldo.

6) A convivência com Jubiabá, cujo conhecimento das plantas que curam doenças e cujos feitiços dominam as forças de pensar do moleque Antônio Balduíno. Jubiabá é uma sorte de patriarca (p. 30) daquela comunidade; é uma presença, uma sorte de força primitiva depositária de sabedoria e bondade com a qual sempre se pode contar. Jubiabá é um modelo a ser seguido pelo menino Balduíno. De outro lado, a leitura de mundo que Jubiabá pratica é uma leitura mágica: "O lobisomem é senhor branco" (p. 48), o feitiço resolve os males do amor, cria doença braba, muda a vida das pessoas. Há uma força espantosa de Jubiabá sobre o menino, um envolvimento que extrapola o normal. Além do que, "Jubiabá era o mistério", p. 29.

7) A estória de Zumbi dos Palmares - Antônio Balduíno se imagina herói como aquele líder negro.

8) O conhecimento da exploração do homem - homens, mulheres e crianças trabalham muito, mas a vida é dura e não paga a pena ser vivida. Internalizam a eternidade da dominação e da exploração: "não se revoltavam porque desde há muitos anos vinha sendo assim" (p. 41). Donde uma subterrânea noção que Antônio Balduíno ia aprendendo: homem livre $x$ homem escravo. A nobiliarquia da gente branca: tio, pai, avô; o político, o doutor, o engenheiro, o proprietário. A traditio de negros e mulatos: "escravidão ao senhor branco e rico" (p. 41). Apenas Jubiabá continha a memória da liberdade dos tempos de África. Se algum homem do morro queria ser livre, era perseguido pela polícia (o braço repressivo dos ricos): Jubiabá e Zé Camarão - "um por macumbeiro, outro por malandragem" (p. 41-2). Malandro é o que se nega a trabalhar para os ricos no regime vigente. Não há que dar espaço para o entendimento da liberdade. Essas coisas vão entrando para a consciência inteligente de Antônio Balduíno, que vai formando um novo conceito: o da revolta. As estórias que ouve, os exemplos que convive formam-lhe, aos poucos, uma nova consciência. Aos poucos, dá para entender que o jagunço não é apenas um bandido, um fora-da-lei - ele o é na óptica do proprietário; sob o ponto de vista de oprimido, é um libertador. Aperfeiçoando a noção de jagunço, dá para chegar ao revolucionário. Do mesmo modo, a grande imagem visual das tatuagens que negros 
mais antigos possuíam nas costas: os lanhos indeléveis da chibata. Havia que se opor a qualquer tipo de chibata. Assim, Antônio Balduíno vai aprendendo. Em igual sentido, o nome do morro - Morro do Capa-Negro: o senhor branco mandava castrar os negros que não reproduziam (não punham no mundo mais negros para servir à escravidão). Nesse momento (p. 48), há um interessante diálogo entre Jubiabá e Zé Camarão, no qual o malandro diz que o senhor branco que experimente vir capá-lo para ver o que acontece. Além disso, não há mais escravidão, "negro não é mais escravo". Antônio Balduíno ouve a resposta de uma personagem que estava ali perto: "Negro ainda é escravo e branco também [...] Todo pobre é ainda escravo. Escravidão ainda não acabou" (p. 48). Todos baixam a cabeça, Antônio Balduíno não, pois ele "não ia ser escravo".

Dá para ver que estão traçados os rumos do protagonista. O livro, aos poucos, vai desenvolver essa problemática.

\section{A NATUREZA DO AMOR}

O amor não deixa de ter sua complexidade, explicável do modo que segue. Antônio Balduíno ama Lindinalva - foi uma descoberta que veio sendo feita aos poucos, em construção permanente. De brincadeiras na infância até algo que domina o negro por completo, o amor por Lindinalva se impõe. Nada o substitui. Mas, ele: negro, pobre, desejo; ela: branca, rica, desprezo. Há que resolver o impasse. E a resolução traz à tona a subjetividade de Antônio Balduíno - a subjetividade dá ao ser humano sua condição e humanidade. Ela se constrói sob os embates consigo mesmo, num conquista do conhecimento.

Num primeiro momento, Antônio Balduíno ama Lindinalva, descobre-a no jeito, nos atrativos, nas pequenas singularidades: 0 alumbramento da primeira visão, o riso de Lindinalva, as brincadeiras de crianças ("ficaram amigos", p. 60), já não pensa mais em fugir [o conceito de fuga é importante no processo de formação da subjetividade de Antônio Balduíno] da casa do comendador e admira cada vez mais a menina (p. 60). Com o passar do tempo, Antônio Balduíno já a observava "com uns olhos religiosos" (p. 64) Lindinalva, "uma santa", "tinha um rosto de santa" (p. 270), estava 
com dezoito anos. Assim, por toda a vida, "dormisse com quem dormisse, era com Lindinalva que ele dormia" (p. 270). Todos os casos de amor do protagonista foram sublimações do amor por Lindinalva: Maria dos Reis, Joana, Zefa, Regina, Rosenda Rosedá, Arminda (transição?). Quando ele possuía qualquer mulher, seu imaginário estava amando Lindinalva. Antônio Balduíno constrói uma utopia, a qual ele sempre perseguirá. Essa utopia é necessária para ele ir-se modificando. Aos poucos, entende as modificações e limita novos caminhos que, ao cabo, são revolucionários. Ele chega a internalizar, p. 270: "Como as coisas mudam!" Mudaram ele e a realidade. Esta, ao fim, porque sua visão das coisas mudou.

Porém, há o conflito entre o que Lindinalva é e o que ele é. A condição econômica e social da mulher não permite a aproximação. $\mathrm{O}$ texto precisa tirar Lindinalva da riqueza a fim de que ela e Antônio Balduíno possam se aproximar. O caminho que Jorge Amado encontra é o da prostituição de Lindinalva. Dramaticamente, a solução do escritor não está bem colocada, pois não é de presumir que o padrão de vida de Lindinalva se altere tão radicalmente quanto o proposto no texto. Foi preciso empobrecer Lindinalva, através da falência do pai, e jogá-la na prostituição a fim de que ambos se aproximassem e se igualassem. Ela é rica e não dá para aceitar o nível de degradação a que chegou. A coisa é feita de um modo arbitrário e, por isso, é inverossímil - possível, mas não crível.

No começo do livro, pp. 55-7, a narrativa dá uma pista para o que vai acontecer com a moça. É a descrição da Travessa Zumbi dos Palmares, lugar em que está o sobrado no qual ela mora. A rua parece um velho decrépito, é mal calçada, as pedras estão desarrumadas, com altos e baixos nos passeios das casas. A noite (símbolo da morte) parecia chegar na travessa antes que na cidade. Palavras que descrevem o espaço: triste, agonizante, velho, encurvar, ruir, "silêncio de morte", cemitério. São sinais que encaminham para um final ruim. Há dois sobrados na rua. No da direita, o sinal é a foto de um jovem que morreu assassinado - tudo trancado, luto fechado, roupas pretas. Com toda essa recorrência, é de inferir que ao sobrado da frente não restará outro destino que não a degradação e a morte. Que é o que acontece: o comendador vai à falência e morre num bordel de maneira execranda. Lindinalva, já mãe de um filho, enganada pelo noivo, é obrigada a render-se à prostituição. É desse modo que Antônio Balduíno vai reencontrá-la. 
Alcançado o nivelamento, o negro pode se aproximar e possuir Lindinalva. Ela está de porta aberta, no último grau de abjeção. Condenada, vai "ou para a assistência ou para o buraco..." (p. 268). Decadência e degradação. Contudo, há uma outra leitura desse fato. A degradação o é conforme o modo de vida anterior de Lindinalva - aquela moça sardenta, rica, filha do comendador é que está degradada. Para Antônio Balduíno ela está plena, completa e igual a ele. Enquanto prostituta, ele "podia possuí-la no dia que quisesse" (p. 270). Filha rica do comendador $x$ mulher da vida. Porém, ele a desveste dessa característica, pois jamais havia buscado um apenas ser sexual. O entendimento de Antônio Balduíno é outro. Lindinalva é o ser necessário à completação de sua subjetividade. Desse modo, "ele não fica alegre" (p. 271) com o fato de poder possuí-la "na hora que quiser". A realidade se desfigura, ele "se entristece e não olha mais o espetáculo da lua cheia" (p. 271). Mudou o mundo ou mudou ele? O protagonista entende que tanto as coisas quanto ele mudam. As revelações trazem um outro conhecimento, muito mais radical. O que o texto faz é o seguinte: ele se livra daquela Lindinalva do sobrado, sem desvesti-la dos, para ele, predicados superiores- linda, alva e santa ${ }^{1}$. São seres humanos no processo de formação da subjetividade - há uma substância Lindinalva que supera a degradação. É essa substância que permite a Antônio Balduino possuir Lindinalva em todas as mulheres que ele teve (ela é alencarianamente virgem e pura $)^{2}$. Antônio Balduíno retira de Lindinalva o conteúdo degradado, deixando apenas a substância pura. A partir daí, é fácil entender por que ele está infeliz no momento em que pode, hora e dia que quiser, possuí-la - incorpora uma outra noção de amor, mais amplo do que aquele que vinha praticando. $O$ amor que ajuda a construir a subjetividade e dimensiona o homem em sua humanidade.

1 O romance nem cogita de raça (branco, negro ou amarelo) ou forma (gordo ou magro, alto ou baixo, tipo de voz).

2 "Só o negro Antônio Balduíno, que nunca dormiu com ela, a possuiu e de todas as formas, no corpo virgem da dos Reis, nas ancas que dançavam de Rosenda Rosedá. só ele a possuiu no corpo de todas as mulheres que dormiram com ele. Na maravilhosa ventura de amor do negro Antônio Balduíno e da branca Lindinalva esta foi branca, preta e mulata, foi também aquela chinesinha do Beco de Maria Paz, foi gorda e magra, teve uma voz masculina certa noite no cais, mentia como a preta Joana" (p. 245). 
Essa operação é difícil porque é transformadora. Antônio Balduíno havia levado a vida inteira para chegar a Lindinalva e agora, que pode tê-la, ele nada consegue. O texto (pp. 270-2) constrói uma série de indagações (na verdade, uma série de angústias). Os pensamentos do negro colidem com a cena vivida: aparece na rua "um trapo, uma figura que perdeu o nome". A seguir, usa palavras que metaforizam o momento de transformação de Antônio Balduíno: frio, tremor, febre, medo, correr, fugir, terror profundo. O momento de tremor e terror advém do choque entre as duas situações: a Lindinalva sonhada contra a Lindinalva contemplada. A catarse se opera mediante um retorno ao regaço materno. No caso, Antônio Balduíno corre para Jubiabá: "E tremendo de medo, tremendo de pavor, sai a correr ladeira acima e só tem descanso na casa de Jubiabá, chorando junto ao pai-de-santo que o acaricia" (p. 271-2 - note as funções maternas de consolo e proteção).

Há duas Lindinalvas: a de agora e a que corria no parque e brincava com o negrinho - a voz ata as duas pontas: "voz doce, voz que recorda aquela outra Lindinalva" (p. 271). O primeiro momento confunde as duas; aos poucos, há a separação e a assunção da que Balduíno construiu para si - ela sai da primeira e se livra da segunda. A morte tem ação restauradora e "ela tornou a ser a mesma Lindinalva da Travessa Zumbi dos Palmares. Seu rosto está sereno e belo. Seu. rosto sardento, rosto de santa. As mãos que tocavam piano e machucavam as rosas são as mesmas. Nada resta da Lindinalva da Pensão Monte Carlo, da Linda da Rua de Baixo, da Sardenta da Ladeira do Tabuão" (p. 272).

Antônio Balduíno tenta salvar Lindinalva através de Jubiabá, mas isso é impossivel, já que Jubiabá deve sair da relação, pois Antônio Balduíno tem que se definir por ele mesmo. O caminho não é mais o de Jubiabá. De outro lado, a morte de Lindinalva é a morte de Antônio Balduíno - o texto sinaliza essa procura da morte por diversas vezes, sobretudo pelo encontro do caminho do mar. Porque não tem um norte, não tem clareza sobre sua destinação, Antônio Balduíno vai seguir o caminho dos que se suicidaram (Salustiano velho que não tem mais colocação no mercado de trabalho; Viriato, o Anão - solidão existencial). Nesse momento de crise, mais que nunca, Balduíno entende que seu caminho é o suicídio, já que com a morte de Lindinalva, "ele ficará só, sem nenhum motivo para viver" (p. 273). 
A remissão do negro se dá pelo reconhecimento de Lindinalva (pronúncia do nome, pedido de perdão e pedido para que ajude a criar seu filho); pela rendição, o arrojar-se "aos pés da cama como um negro escravo" (a palavra escravo longe está da conotação anterior); pelo hino de amor que ele entoa (aquele conceito de virgem e pura); por se tornar operário ("ia ser escravo da hora, dos capatazes, dos guindastes e dos navios. Mas se não o fizesse só lhe restaria entrar pelo caminho do mar", p. 275).

Desse modo, é possível um abecê de Antônio Balduíno, pois ele transpõe barreiras dificeis.

\section{TEORIA DO ESCRAVO}

Jubiabá está dividido em três partes: "Bahia de todos os santos e do pai-de-santo Jubiabá", "Diário de um negro em fuga" e "A.B.C. de Antônio Balduino".

A primeira parte desenvolve as várias tendências de Antônio Balduíno: lutador de boxe, cangaceiro (quando crescer, vai querer ser jagunço, p. 27), malandro, capoeirista, sambista. Há um leque de possibilidades - a mais clara: a marginalidade. Disso, porém, a narrativa não cogita, pois o texto sustenta que Antônio Balduino tem uma "infầncia sadia", p. 29. O protagonista ouve as estórias e aprende. Sobretudo, há o aprendizado mágico com Jubiabá: a prática do curandeirismo, o sincretismo religioso, as rezas, amuletos como proteção (figa, p. 54), o jogo entre brancos e negros, o sentido ultrapassado de escravo, a ética maniqueísta do bem e do mal (olho da piedade e olho da ruindade - olho vazado), a eternidade da dominação e da exploração, homem livre $x$ homem escravo, o destino humano "é coisa feita lá em cima" (p. 34) - depois, Antonio Balduíno vai entender que os fatos humanos são construidos e desconstruidos pelo proprio homem e que é possivel mudar o rumo da história pela vontade e pela determmaçũo da consciência e do trabalho. O medo pânico que os meninos c' mesmo os adultos - têm de Jubiabá, pois cle guarda os segredos do além, cura as moléstias pela reza, sabe de despachos para lazer ou desfazer, tem "o diabo preso numa garrafa" (p. 29), vira lobisomem. detém os segredos da linguagem não conhecida (nago). anda sempre com um ramo de folhas na mão (p. 29). A mesma killura magkia se esparrama na visão de mundo de 
outras personagens: o espírito que vive encostado em Augusta (pp. 423): a forma mágica de relatar o conhecer: "o lobisomem é senhor branco" (p. 48), na explicação do nome do morro (Morro do Capa Negro); o próprio Antônio Balduíno quer virar lobisomem e pratica os atos para isso (pp. 44-5); Afinal, todo um rol mágico de saberes que o texto constrói e deixa o protagonista ir internalizando. Dentro desse universo, cria-se o menino. Essas coisas, de começo, fazem o seu conhecer e o seu conhecer-se.

O protagonista comunga com o mundo, deixa-se envolver por ele, aprende-lhe o modo de ser, admira-o e se entusiasma.

Pode-se experimentar uma dificuldade que o livro não consegue resolver: se é uma forma mágica de cosmovisão que Balduíno internaliza, e durante o período básico de formação da consciência, por volta dos sete/oito anos de idade, como é que ele se vai haver, depois, para se tornar o homem materialista, ateu, comunista, líder operário e herói de um mundo novo?

Nessa primeira parte aparece, ainda, a descoberta do amor; o conceito de fuga (o fugir da casa do comendador, pai de Lindinalva, pp. 59 e 65; a fuga de Zumbi, pp. 62-3; o "fugir pelo mar num saveiro", p. 137; a grande fuga que centraliza um rito de passagem, pp. 172-82); a noção de liberdade, corolário da fuga; a vida comunista dos meninos de rua; o prazer de viver e a malandragem (gargalhada): os sintomas da crise existencial - solidão, morte, angústia, família, amor, desespero, ódio, o desconhecer a Bahia; o primeiro entendimento para a formação do operário revolucionário; o gosto por brigar e o significado da luta; o encontro da arte; a percepção da sociedade exploradora.

Ao lado das conquistas, algumas derrotas graves que fazem o protagonista mudar o rumo de sua vida.

A segunda parte - "Diário de um negro em fuga" - tem, como vértice principal, um rito de passagem. Ele se justifica pelo que aconteceu anteriormente. A derrota para Miguez, o lutador peruano, é o climax das coisas que vinham se processando na vida de Antônio Balduíno. O fato de ele não mais reconhecer a Bahia, de estar triste e sem rumo, exigem novo caminho, nova vida. E a nova vida opera modificações profundas no ser.

A situação inicial é a de negros $x$ brancos. 
Os negros são lavadeiras, cozinheiras, engraxates, recadeiros, jornaleiros, crias, "curvos sob o peso dos sacos de cacau" e empregados "nas fábricas enormes" (p. 41). Moram no morro e habitam casebres (de palhas).

Os brancos são médicos, advogados, engenheiros, comerciantes, homens ricos, políticos e toda a linha bacharelesca (discursadores). Moram na cidade e habitam casas.

Entre os brancos há tradição familiar (memória de um político sagaz, de um homem célebre, um avô ou um tio de nomeada); entre os negros, a única tradição é a da escravidão. Os negros (pobres) moram nos morros para servirem aos brancos (ricos). Os negros internalizam a perenidade dessa situação: o mundo sempre foi assim e não dá para mudá-lo - sempre houve os que têm e os que não têm; os protegidos da sorte e os desafortunados. O negro existia para servir "ao senhor branco e rico". A memória da liberdade, na África, está perdida. Livro de enseñanza que é, Jubiabá vai transformar, pela consciência e pela luta, a posição de Antônio Balduíno.

Excurso: na p. 42, Jorge Amado comete um equívoco, ao dizer que o protagonista "resolveu ser do número dos homens livres". Como se, numa sociedade organizada, isso pudesse ser assim, por uma apenas escolha. A pessoa não pode resolver ser e ser. É um processo e envolve luta, conhecimento e consciência crítica de classe. A narrativa desmente o autor. Outra coisa que vai ser desmentida pela narrativa é aquela escola (p. 27), recomendada ao menino. Do mesmo modo, é inverossímil que Jubiabá estivesse "lendo um velho livro", na p. 53. A escola referida no texto é a que ensina ao menino branco, não ao negro. Grosso analfabetismo grassa por todos os cantos do Brasil e não é de se pensar que negro não fosse senão analfabeto. Jubiabá tem sabedoria, mas não é letrado. No segmento da p. 42, o romance sabe que o saber de Antônio Balduíno vem das "histórias heróicas", do exemplário das modinhas e cantorias ouvidas. E da viva vivida.

No segmento inicial, ainda, a voz de um trabalhador no cais amplia o entendimento de escravo. Todos baixam a cabeça às suas palavras (resignação, não saber o que fazer, aceitação). Só Antônio Balduíno ficou de cabeça erguida, como a dizer que compreendia e que tinha um norte a seguir. A voz, pela primeira vez, mostra que brancos e negros são escravos: "todo pobre é ainda escravo" (p. 48). É impossivel, ao protagonista, entender o que isso significa, que o 
problema é de classe e não de raça. Sobretudo porque ele está sob sugestão de Jubiabá: o senhor branco é lobisomem que está no mundo purgando (?) as ruindades que cometeu (mandava capar os negros que não reproduziam = não produziam novos escravos - donde o nome do morro, Morro do Capa Negro).

Na verdade, na cena, há um choque de quatro vozes:

a) voz mágica - conjuração do ente maléfico pela invocação deica (acolhe a forma mágica do relato de Jubiabá);

b) voz irônica - Zé Camarão, um dos seres livres do romance, debocha e desafia;

c) voz literal - negro não é mais escravo (observar a função opositiva e admirativa do "mas");

d) voz crítica - negros e brancos - pobres - ainda são escravos.

Para sair da condição histórica de escravo, há que desembaralhar as coisas que estão misturadas. É a função do conhecimento. E o protagonista tem qualidades para isso: é Antônio Balduíno quem pensa, quem tem idéias (p. 49).

Antônio Balduíno vai viver - porque não dá para ficar só ouvindo - a experiência do escravo. Vai assumir a voz crítica e partir para a ação a fim de mudar o mundo (revolta > revolução).

É possível acompanhar os passos dessa transformação:

1) É metido numa clausura - ele, "o mais livre" é jogado "na casa de um senhor" (p. 59). Para fazer aquelas coisas que cabem ao escravo fazer.

2) $\mathrm{Na}$ casa do comendador (rico) sofre o primeiro revés da discriminação racial (preconceito do europeu): a cozinheira portuguesa - considera-o escravo ("negro é uma raça que só serve para escravo", p. 60), ignorante ("não nasceu para saber", p. 60) e concupiscente (olhar as coxas de Lindinalva, p. 64, e espiar pelo buraco da fechadura quando a moça tomava banho, p. 65). Fica implícito no episódio: branco pobre $x$ negro pobre.

3) Atualização, através do pesadelo, do negro "com as costas marcadas" (p. 134). Antônio Balduíno se angustia como se a coisa loda estivesse acontecendo naquele momento. Para ampliar o clima de 
ódio (negros e brancos), Jubiabá narra a fábula dos gorilas (pp. 134-6). $\mathrm{Na}$ última linha da cena, Antônio Balduíno "segura o punhal na altura do peito": matar-se (graças à angústia que dele se apossa) ou matar os marinheiros brancos que estão bebendo ali ao lado? Não há resposta, mas deve ser a segunda opção. [Notar que esse marinheiro loiro que ele quer agora matar por ódio, vai ser o emissário da boa nova da greve e do novo herói do mundo, no final da narrativa, p. 318.]

4) Já na região fumageira, Antônio Balduíno ouve relatos e constata fatos sobre as contradições entre a vida dos trabalhadores e a dos proprietários (negros $x$ brancos). A miséria é tão grande que as mulheres são incapazes de amor. Diante disso, o protagonista declara que sua vontade "é matar os brancos todos" (p. 154). Ainda aqui. Antônio Balduíno comete o erro de perspectiva histórica, que, de resto, aos poucos, vai corrigindo. O problema é de classe, não de raça. Aliás, na cena toda, o problema está colocado. Balduíno é que, por enquanto, não consegue percebê-lo.

5) Antônio Balduíno "matou" Zequinha (p. 172) porque este era representante dos patrões ou foi apenas caso isolado? Deixando de lado a segunda alternativa, há alguns indícios fortes em favor da primeira. A densidade muito alta das tensões entre os que tudo têm e os que nada têm (o horror da miséria em que vivem as pessoas); a certeza de que ele não "matou" Zequinha devido a Arminda, uma menina de doze anos que o capataz possui ("ele sabe que não foi por isso que cravou o punhal nas costas de Zequinha". p. 175); o ódio instalado no coração de Antônio Balduíno; os três indicativos de que os patrões querem pegar Balduíno, como se a punhalada tivesse sido neles: a) "Engraçado é que ninguém gostava de Zequinha e todos gostavam dele. Mas a patrão mandou, com certeza, e quem não for cercar o criminoso será despedido do trabalho... (p. 179). b) "O patrão está mesmo disposto a liquidar o negro Antônio Balduino" (p. 181). c) [...] "o patrão queria pegar Balduíno" (p. 183).

6) Um biblia que está na feira (pp. 240-1) opõe o novo ao velho, o carro ao cavalo, no fundo, o diabo a deus. O velho e o cavalo são melhores e não causam problema. O bíblia diz uma série de tolices, contestadas por Antônio Balduíno e por Jubiabá. Este é taxativo: "No tempo do carro de boi tinha negro com fome. Hoje também tem. Pra negro é a mesma coisa". E um mulato velho amplia 
o discurso: a coisa vale para negro e para pobre. A percepção menor fica alargada e a compreensão da totalidade está crescendo.

7) Antônio Balduíno compõe um abecê sobre Zumbi dos Palmares, contando-lhe a vida livre na África e o fato de ele ter sido enganado pelos brancos. Feito escravo, rebela-se e "luta contra a escravidão", afirmando que não é escravo (pp. 246-7). Os brancos (o poeta que lhe comprava os sambas) não querem comprar o abecê, já os negros acham o texto "uma beleza": o sentido desalienador da arte.

8) Na seqüiencia da narrativa, o negro vai saindo da lide, vai entrando o pobre. O texto se vai transformando: o problema não é de raça, é de classe. Durante a greve dos condutores de bonde, dos operários da força e luz e da telefônica, um bêbado xinga os negros grevistas (Antônio Balduíno dá-lhe um murro que o estatela no chão não esquecer que Balduíno adora uma briga). Jubiabá faz a leitura do fato: "todo pobre agora já virou negro" (p. 278).

9) Severino faz um discurso para os trabalhadores do cais ( $p$. 279), revelando que "são todos irmãos".

10) A fome, devido à exploração, está na casa de todos os trabalhadores (brancos e negros $=$ pobres). Muitas pessoas já percebem as contradições sociais e econômicas: "A gente é negro, eles são brancos, mas nesta hora tudo é pobre com fome" (p. 280). Fica evidente o novo sentido de classe social, a classe dominada começa a lutar por seus direitos.

11) Na p. 281, a tese do romance: "Eles podiam deixar de ser escravos". Jorge Amado não desconhece o poder da vontade das pessoas, pois quando "eles queriam, ninguém podia com eles". Eles tinham a cidade nas mãos. A transformação é visível.

12) As coisas, porém, não se operam de maneira completa. Há que lutar, insistir, mostrar a todos as contradições até chegar à consciencia crítica e à ação modificadora do real. O texto sabe disso e Antônio Balduíno já internaliza essa posição: em novo abecê. Balduíno canta a beleza da nova briga da qual participa - o sentido revolucionário da luta: "Os trabalhadores são escravos, mas estão lutando para se libertar" (p. 316). Donde: luta > revolta > revolução. 


\section{REFERÊNCIAS BIBLIOGRÁFICAS}

- Livros de Jorge Amado aproveitados para este ensaio:

Jubiabá, 1935 [12. ed., São Paulo, Martins, 1963].

Capitães da areia, 1937 [82. ed., Rio de Janeiro, Record, 1995].

Terras do sem fim, 1942 [48. ed., Rio de Janeiro, Record, 1982].

São Jorge dos Ilhéus, 1944 [52. ed., Rio de Janeiro, Record, 1999].

Seara Vermelha, 1946 [49. ed., Rio de Janeiro, Record, 1998].

Gabriela, cravo e canela, 1958 [75. ed., Rio de Janeiro, Record, 1994].

Dona Flor e seus dois maridos, 1967 [48. ed., Rio de Janeiro, Record, 1997].

Tereza Batista cansada de guerra. São Paulo, Martins, 1972.

Tieta do agreste, 1977 [23. ed., Rio de Janeiro, Record, 1997].

- Livros consultados para a produção do ensaio:

ATAIDE, Vicente. Literatura infantil e ideologia. Curitiba, HD Livros, 1995.

CAUDWELL, Christopher. O conceito de liberdade (trad. bras.). Rio de Janeiro: Zahar, 1968. [Cf., para este estudo, os capítulos sobre o amor, p. 30, e sobre a beleza, p. 74.]

CHASIN, José. O integralismo de Plinio Salgado: formas de regressividade do capitalismo hipertardio. São Paulo: Ciências Humanas, 1987.

FAORO, Raimundo. Os donos do poder: formação do patronato político no Brasil. 9. ed. 2v. São Paulo: Globo, 1991.

FERNANDES, Florestan. A revolução burguesa no Brasil. 2. ed. Rio de Janeiro: Zahar, 1976. 
LEAL, Vítor Nunes. Coronelismo, enxada e voto. 3. ed. São Paulo, Alfa-Omega, 1976.

PRADO JÚNIOR, Caio. Formação do Brasil contemporâneo. 13. ed. São Paulo: Brasiliense, 1973.

SILVA, Hélio. Terrorismo em campo verde. Rio de Janeiro: Civilização Brasileira, 1972.

SINGER, Paul. A formação da classe operária. 4. ed. São Paulo: Atual; Campinas: Editora da UNICAMP, 1987.

SODRÉ, Nelson Werneck. História da burguesia brasileira. 4. ed. Petrópolis: Vozes, 1963.

TRINDADE, Hélgio. Integralismo: o fascismo brasileiro na década de 30. São Paulo, Brasiliense, 1962. 